\title{
pemerintahan marga di lubuklinggau TAHUN 1855-1983
}

\author{
GOVERNMENT CLAN IN LUBUKLINGGAU \\ AT 1855-1983
}

\author{
Eka Apriyanti \\ Reiza D. Dienaputra \\ Universitas Padjadjaran, Jln. Raya Bandung-Sumedang Km. 21 Jatinangor Sumedang 45363 \\ e-mail: echabim@rocketmail.com
}

Naskah Disetujui:30April 2015

\begin{abstract}
Abstrak
Sistem Pemerintahan Marga di Lubuklinggau berlangsung sejak tahun 1855 pada masa Pemerintahan Hindia Belanda. Tahun 1983 sistem Pemerintahan Marga di Lubuklinggau berakhir berdasarkan Surat Keputusan Gubernur Daerah Tingkat I Sumatera Selatan Nomor: 142 tahun 1983. Pemerintahan Marga pertama kali dikenal dalam wilayah Kesultanan Palembang Tahun 1662-1706. Marga dibentuk pada umumnya di daerah pedalaman, yang berada di hulu sungai. Tujuannya untuk memudahkan pengaturan wilayah kesultanan yang luas. Setiap Marga dipimpin oleh seorang kepala Marga yang disebut Depati/Pesirah. Sistem Pemerintahan Marga berlangsung hingga Masa Kemerdekaan. Sumber informasi mengenai pemerintahan Marga antara lain Piagam dari Sultan Palembang untuk Kiai Ario dari IPIL (Sekayu), stempel cap Marga Suku Tengah Kepungut Moesi Oloe di Lubuk Besar tahun 1856, dan Piagam Moeara Katie Marga Suku Tengah Tiang Poeng-poeng Afdeeling Moesi Oloe tahun 1866. Untuk menjelaskan sistem Pemerintahan Marga yang berlangsung cukup lama di Lubuklinggau kajian ini menggunakan metode sejarah. Interpretasi diperkuat dengan menggunakan konsep dan teori dari ilmu sosiologi, antropologi, dan ilmu politik. Kajian meliputi tiga hal, yaitu lahirnya pemerintahan Marga, hukum dalam pemerintahan Marga, dan pemerintahan Marga di Lubuklinggau.
\end{abstract}

Kata kunci: Marga, Pesirah, Depati, Lubuklinggau, Undang-undang Simbur Cahaya.

\begin{abstract}
The Clan Government administration systemof Lubuklingau had been role since 1855 in the Government of the Netherlands East Indies. It ended in 1983 by the Decree of the Governor of South Sumatra Level Region Number: 142 year 1983. The Clan Government Administration was known firstly in the Sultanate of Palembang Year 1662-1706. Margaor clan was formed generally in rural areas, which was closed to the river. The aim was to facilitate the controlling of the sultanate vast territory. Each of the clan was led by a head of Margawhich was called Depati / Pesirah. This system lasted until the Independence Period. The information sources about the government of clans can be seen from the Charter of the Sultan of Palembang to Kiai Ario of IPIL (Sekayu), stamp of the clans of Middle Kepungut Moesi Oloe in Lubuk Besar in 1856, and the Charter of Moeara Katie Middle Pillar Poeng-Poeng Afdeeling Moesi Oloe clan in 1866 . To explain the government system of Lubuklingau clan in this research,the researcher used the historical method. The Interpretation is reinforced by the use of concepts and theories of sociology, anthropology, and political science. The Studies cover three things; the birth of clan governance, rule of law within the clan, and the clan rule in Lubuklinggau.
\end{abstract}

Keywords: Highways/clan, Pesirah, Depati, Lubuklinggau, Law of Simbur Cahaya. 


\section{A. PENDAHULUAN}

Marga dikenal sebagai kesatuan pemerintahan terendah di wilayah Provinsi Sumatera Selatan. Namun, tulisan yang komprehensif mengenai perkembangannya secara evolusioner yang bermula dari budaya masyarakat Palembang meliputi kurun waktu dari titik awal hingga sekarang belum ditemukan. Kata "Marga" ini pertama kali didapati dalam piagampiagam Sultan Palembang sejak 1760-an. Ambtenaar Belanda dan Inggris seperti Mars, Raffles, dan Knoerle dalam setiap karangan mereka tidak pernah menyebutkan istilah Marga, namun mereka menyebut sebagai kesatuan masyarakat dengan istilah Petulai, Sumbai, Kebuaian atau Suku, kesatuan-kesatuan tersebut sebagai suatu kesatuan yang bersifat genealogis (Muslimin, 1986: 9).

Pemerintahan Marga ${ }^{1}$ pertama kali dikenal dalam wilayah Kesultanan Palembang dan dibentuk pada masa Kesultanan Palembang Sultan Cindeh Balang (1662-1706). Marga ini dibentuk bertujuan untuk memudahkan pengaturan wilayah Kesultanan Palembang. Sistem Pemerintahan Marga diatur dalam Undangundang Simbur Cahaya. ${ }^{2}$ Undang-undang

\footnotetext{
${ }^{1}$ Marga pada dasarnya adalah daerah teritorial di bawah kekuasaan Kesultanan Palembang. Marga merupakan satuan pemerintahan yang membawahi beberapa dusun di bawah pimpinan seorang pesirah/depati. Panggilan pesirah/depati adalah pangeran. Ia bertindak sebagai kepala hukum adat yang menjalankan keputusan, undang-undang serta ketentuan yang tercantum dalam piagam yang dikeluarkan oleh Sultan. Aturan yang harus diikuti oleh pesirah/depati mengenai aturan Marga tercantum dalam Undang-undang Simbur Cahaya (Suwandi, 1995: 19).

2 Undang-undang simbur cahaya merupakan kumpulan peraturan hukum adat yang dulu berlaku di Keresidenan Palembang di luar Ibukota Keresidenan (Palembang), kumpulan hukum adat tersebut bukanlah undang-undang dalam arti produk legislatif dari suatu Dewan Perwakilan Rakyat seperti dikesankan oleh namanya. Maksud diberlakukannya UndangUndang Simbur Cahaya tersebut sebagai suatu
}

ini pertama kali disusun di Istana Kesultanan Palembang tahun 1630 dan digunakan di seluruh wilayah Kesultanan Palembang sebagai hukum adat tertulis (Suwandi, 1995: 8).

Pada masa kekuasaan Hindia Belanda di Kesultanan Palembang tahun 1821, pemerintahan kesultanan dihapuskan dan diganti dengan Keresidenan Palembang. Dalam menjalankan pemerintahan, Belanda meneruskan sistem yang telah ada sejak masa kesultanan seperti sistem pemerintahan Marga. Belanda juga membentuk Marga-Marga baru yang dianggap perlu, seperti Marga Sindang Kelingi Ilir yang dibentuk oleh Belanda tahun 1855. Marga Sindang Kelingi Ilir ini beribu kota di Lubuklinggau. Sebelumnya, Lubuklinggau hanyalah sebuah dusun kecil dengan masyarakatnya berasal dari Negeri Ulak Lebar. Mereka dipindahkan secara paksa oleh Pemerintah Hindia Belanda, mengingat lokasi Negeri Ulak Lebar yang tidak strategis untuk perkembangan pemerintahan ke depan. Dengan demikian, pemerintah Hindia Belanda memindahkan masyarakat yang mendiami Ulak Lebar ke hunian baru yang telah disediakan. Marga Sindang Kelingi Ilir dibentuk setelah Pemerintah Hindia Belanda menyusun kembali Undang-undang Simbur Cahaya tahun 1854.

Berdasarkan undang-undang tersebut, semua dusun yang berada di bawah kesatuan suku atau hukum adat yang belum mempunyai Marga harus segera dibentuk. Wilayah dusun atau negeri yang merupakan kesatuan suku atau hukum adat dalam wilayah pengawasan Sindang Kelingi Ilir dihimpun ke dalam Marga-Marga, yaitu: wilayah yang meliputi Dusun Kepala Curup, Padang Ulak Tanding, dan beberapa dusun lainnya sampai dengan perbatasan Lubukdurian masuk ke dalam Marga Sindang Kelingi. Selanjutnya untuk Dusun Lubukdurian,

pedoman untuk hukum adat yang akan diterapkan (Kompilasi Adat Istiadat Kabupaten Musi Rawas, 2001:64) 
Dusun Kayu Ara, Dusun Lubuk Tanjung, Dusun Lubuklinggau, Dusun Kandis, dan Dusun Batu Urip Tue (Tarwe) masuk dalam Dusun Marga Sindang Kelingi Ilir, dengan kepala Marganya berkedudukan di Dusun Lubuklinggau. Oleh karena itu, Dusun Lubuklinggau berstatus Dusun Marga (pusat pemerintahan Marga) tempat kedudukan kepala Marga Sindang Kelingi Ilir.

Status sebagai dusun Marga Sindang Kelingi Ilir ini berakhir tahun 1983. Saat itu semua kesatuan pemerintahan yang disebut Marga dihapuskan dengan perangkat-perangkatnya yang ada dan sekaligus dibentuk pemerintahan desa sebagai penggantinya. Lingkup wilayah pemerintahan desa meliputi wilayah dusun yang berada di bawah naungan bekas Marga yang telah dihapuskan. ${ }^{3}$ Untuk menjelaskan hal ini penulis melakukan penelitian dengan menggunakan metode sejarah dan mengunakan berbagai disiplin ilmu sebagai alat untuk menganalisis tentang Pemerintahan Marga di Lubuklinggau.

Sistem pemerintahan Marga lahir dari budaya dan sistem politik kekuasaan sejak masa Kesultanan Palembang. Sistem Marga ini terus berlanjut hingga zaman kemerdekaan sebagai kesatuan adat yang masih bersifat tradisional dan dilaksanakan atas dasar kekeluargaan. Untuk menganalisis hal tersebut diperlukan berbagai disiplin ilmu seperti sosiologi, antropologi, dan ilmu politik yang memiliki daya analisis lebih tajam untuk mencari kondisi-kondisi kausal dari peristiwa sejarah sehingga dapat memperkuat hasil analisis.

\footnotetext{
${ }^{3}$ Surat Keputusan Gubernur Daerah Tingkat I Sumatera Selatan Nomor: 142 tahun 1983. Tentang penghapusan pemerintahan Marga, DPR, Marga dan perangkat Marga lainnya, pemberhentian pesirah/pejabat pesirah kepala Marga, ketua/anggota DPR. Marga dan pejabat pamong Marga lainnya serta penunjukan pejabat kepala desa dalam wilayah provinsi daerah tingkat I Sumatera Selatan.
}

Sistem pemerintahan Marga bertahan cukup lama di dalam wilayah Sumatera Selatan. Tujuan penelitian ini untuk menjelaskan lahirnya pemerintahan Marga, hukum yang berlaku, serta menjelaskan sistem pemerintahan Marga di Lubuklinggau. Titik fokus kajian lebih diarahkan kepada sumber sejarah lahirnya sistem pemerintahan Marga tersebut. Terungkapnya fakta mengenai pemerintahan Marga ini akan menjelaskan bagaimana sistem pemerintahan tradisional ini dapat bertahan lama dalam wilayah Sumatera Selatan.

\section{B. METODE PENELITIAN}

Dengan mengacu pada maksud dan tujuan penelitian, penelitian ini menggunakan prosedur yang umum digunakan dalam penelitian sejarah. Tujuannya untuk membuat rekonstruksi masa lampau secara sistematis dan objektif (Herlina, 2011:1). Tujuan ini dicapai dengan menggunakan metode.

Metode yang digunakan dalam penelitian ini adalah metode sejarah. "Metode sejarah yaitu proses menguji dan menganalisis secara kritis rekaman dan peninggalan agar peristiwa yang terjadi di masa lampau dapat direkonstruksi secara imajinatif" (Gottschalk, 1985:32). Metode sejarah ini memiliki empat tahapan kerja: heuristik, kritik, interpretasi, dan historiografi.

Tahapan pertama heuristik adalah proses mencari, menemukan, dan menghimpun sumber sejarah yang relevan dengan pokok masalah yang sedang diteliti. Sumber-sumber yang dicari dapat berbentuk sumber tertulis dan benda. Setelah sumber sejarah terhimpun, proses selanjutnya adalah melakukan analisis terhadap sumber. Kegiatan analisis ini disebut kritik sumber. Dalam metode sejarah dikenal dua jenis kritik sumber, yaitu kritik eksternal dan kritik internal. Kritik eksternal dilakukan untuk menentukan otentisitas sumber dengan cara memberikan penilaian terhadap kondisi fisik sumber tersebut, seperti jenis 
kertas yang dipakai, tinta, tulisan, huruf, watermark, stempel, dan sebagainya. Kritik internal ditempuh dengan cara melakukan penilaian instrinsik terhadap sumber tersebut, misalnya menilai penulis atau penyusun sumber tersebut.

Data yang telah lolos dari tahapan kritik kemudian diinterpretasi. Interprestasi merupakan tahapan menafsirkan informasi yang terdapat di dalam sumber yang telah dikumpulkan. Tahapan ini dilakukan karena orientasi penelitian adalah menganalisis masalah yang memiliki porsi lebih banyak. Interpretasi diperlukan untuk membuat data yang tampaknya terlepas satu dengan yang lainnya menjadi satu hubungan yang saling berkaitan, sehingga terlihat jelas kausalitasnya. Dari tahapan interpretasi dihasilkan fakta. Fakta yang dihasilkan dan masih saling terlepas satu sama lain itu kemudian disintesiskan. Setelah itu dilakukan tahapan terakhir, yaitu historiografi atau penulisan sejarah. Semua tahapan ini dilakukan berdasarkan kerangka konseptual yang telah dibuat sebelumnya.

Selanjutnya untuk eksplanasi yang mendalam digunakan pendekatan dari ilmu-ilmu sosial, yakni pendekatan ilmu sosiologi, antropologi, dan politik. Dengan menggunakan pendekatan tersebut, penelitian ini akan menjadi terarah dan sistematis. Pendekatan sosiologi akan meneropong segi-segi sosial peristiwa yang dikaji, seperti golongan sosial mana yang berperan, serta nilai-nilainya, hubungan dengan golongan lain, konflik berdasarkan kepentingan, idiologi, dan lainnya. Sedangkan antropologi sendiri akan mengungkapkan nilai-nilai yang didasari oleh perilaku tokoh sejarah, status dan gaya hidup, sistem kepercayaan yang didasari pola hidup dan lain sebagainya. Terlebih penting dalam penelitian adalah mengenai politik di mana dalam segi pendekatan politik akan menyoroti kekuasaan, jenis kepemimpinan, hirarki sosial, pertentangan kekuasaan, dan lain sebagainya (Sartono, 1992:4).

\section{HASIL DAN BAHASAN}

\section{Lahirnya Pemerintahan Marga}

Secara kronologis tidak ditemukan tulisan mengenai sejarah perkembangan kesatuan pemerintahan yang disebut Marga. Menurut van Royen dalam catatannya tentang Marga di Palembang, ia menggambarkan perkiraan perkembangan sistem Marga dalam beberapa tahap. Tahap yang tertua ialah adanya rumpun orang yang hidup mengembara dan berpindahpindah dari suatu tempat ke tempat yang lain yang disebut nomad, yang tidak mempunyai tempat tinggal tetap. Mereka ini merupakan suatu kelompok yang hidup dari mengumpulkan hasil hutan, perburuan hewan dan penangkapan ikan. Sisa-sisa dari kehidupan ini ialah orang-orang Kubu yang hidup jauh masuk ke pedalaman. Orang-orang Kubu ini sedikit menerima pengaruh asing. Sementara kelompok masyarakat yang sudah banyak menerima pengaruh asing adalah yang bermukim di daerah-daerah tepi pantai atau sungaisungai. Orang-orang Kubu ini yang masih didapati di Sumatera Selatan dalam rumpun-rumpun yang bersatu dan diikat oleh tali kekeluargaan. Jadi, tipe kelompok orang-orang Kubu inilah yang dianggap sebagai asal mula kesatuan genealogis, yang merupakan benih pertama dari masyarakat hukum adat. Orang-orang Kubu ini masih banyak terdapat di wilayah pedalaman Kabupaten Musi Rawas.

Dalam tahap kedua telah terjadi peningkatan pola hidup, dari pengembara menjadi penghuni sementara daerah atau wilayah tertentu. Mereka menunjukkan gejala ingin menetap dan mencari nafkah sumber kehidupannya dari bertani di ladang yang berpindah-pindah. Mereka berpindah dari satu area perladangan ke area perladangan lain dalam jangka waktu beberapa tahun. Perpindahan ini berhubungan dengan kondisi kesuburan tanah. Dari kelompok-kelompok setengah pengembara ini timbul dusun-dusun semi permanen yang masih diikat dalam kesatuan oleh tali kekeluargaan. Anggotanya bersatu karena masih 
seketurunan dari nenek moyang tertentu. Pada tahun 1927, Van Royen menuliskan contoh dari sisa masyarakat tersebut disebut sebagai "anak Lakitan". Tipe kesatuan masyarakat ini berkembang sekitar tahun 1859 dengan Marga Batu Kuning Lakitan. Sementara Marga Batu Kuning Kelingi hidup di pinggir-pinggir dan di muara-muara anak-anak Sungai Lakitan.

Pada tahap ketiga, dari kesatuankesatuan masyarakat yang berladang berpindah-pindah dari ladang/talang ke ladang/talang dalam kurun waktu lebih kurang 2 tahun, kemudian timbul dusundusun yang bersifat permanen. Masingmasing rumpun keluarga biasanya menghuni suatu daerah yang mempunyai batas-batas alamiah seperti lembahlembah. Dalam satu wilayah permukiman, tinggal satu atau lebih rumpun keluarga yang berasal dari satu nenek moyang. Anggota-anggota rumpun keluarga sebagian besar tetap hidup dari pertanian menetap dengan cara yang sudah lebih maju. Contohnya, tahun 1916 di daerah Rejang Lebong antara lain terdapat rumpun keluarga yang terkemuka seperti Petulai Jurukalang, Bermani, Selupu, dan Subai (daerah ini masih termasuk lingkaran adat Sumatera Selatan, sekarang termasuk dalam wilayah Provinsi Bengkulu). Menurut Pangeran Muara Danau (dalam Muslimin, 1986: 7) tahun 1825 di empat Lawang telah berkembang sembilan rumpun orang-orang Rejang, yaitu Semidang Sakti, Bungo Sakti, Semintal Sakti, Juru Talang Sakti, Selapo Sakti, Marigi Sakti, Brahmani Sakti, Serai Sakti, dan Piagu Pring Sakti.

Pada tahap keempat terdapat perkembangan sedemikian rupa, sehingga telah terbentuk rumpun-rumpun yang menetap di suatu lokasi. Jika kemudian suatu lokasi mulai dirasakan sempit, karena anggota dalam setiap rumpunrumpun ini terus berkembang. Maka beberapa rumpun harus berpindah lokasi ke tempat yang agak jauh, tetapi masih dalam suatu kesatuan daerah geografis.
Biasanya hubungan kekeluargaan belum terputus dan masih dalam satu keturunan dari satu nenek moyang, karena itu jarak antara dusun induk dan dusun baru tidak saling berjauhan. Rumpun kekeluargaan seperti ini disebut kabuian.

$$
\text { Dalam perkembangan tahap }
$$
keempat ini didapati hubungan kekeluargaan yang erat, biar pun sudah berpisah tempat tinggal dari dusun induk karena status mereka masih satu keturunan dari satu nenek moyang. Pada tahap permulaan perkembangan ini masih tetap dirasakan ikatan kekeluargaan satu keturunan. Seiring berjalannya waktu, dalam perkembangan selanjutnya didapati masyarakat dari luar yang menetap dan menempati areal tersebut.

Tahap kelima, dalam suatu daerah tertentu secara geografis tidak hanya terdapat rumpun keluarga satu keturunan, tetapi juga ada rumpun keluarga pendatang. Percampuran ini kemudian merupakan kesatuan mandiri dan merasa satu keturunan meski berasal dari nenek moyang yang berbeda. Antara rumpun keluarga asli dan pendatang bersatu meski tanpa ada percampuran antara rumpun itu. Biasanya rumpun yang kecil dan datang kemudian mengakui wibawa lebih (supremasi) dari rumpun keluarga asli di suatu daerah. Dari asal usul keluarga yang tidak satu rumpun dan berbeda-beda garis keturunan, lama-kelamaan garis keturunan itu menjadi kabur dan yang lebih menonjol adalah sifat teritorial masyarakat (masyarakat yang diikat oleh kesatuan tempat bermukim). Sebagai ilustrasi, rumpun Pasemah yang berpindah dan bermukin di Semendo Darat membentuk kesatuan masyarakat menjadi Marga Semendo, Makakau, Bayan, dan Kisam. Di sini timbul kesatuan masyarakat yang sifat teritorialnya lebih menonjol; sementara sifat genealogisnya menyurut. Dalam perkembangan inilah timbul nama Marga sebagai suatu kesatuan masyarakat yang lebih bersifat teritorial (Muslimin, 1986: 59). 
Istilah "Marga" berasal dari bahasa Sansekerta "varga" yang mengandung makna dalam suatu teritorial tertentu maupun rumpun dan keluarga (genealogis). Sebelum diperkenalkannya sistem Marga, masyarakat hukum adat Rejang telah mengenal sistem Ketue. Ketue adalah suatu kesatuan masyarakat hukum adat tunggal dan genealogis, dengan pemerintahan yang berdiri sendiri dan bersifat kekeluargaan. Kata Marga ini pertama kali didapati dalam piagampiagam Sultan Palembang sejak tahun 1760, namun Mars, Raffles dan Knoerle tidak pernah menyebut istilah Marga dalam tulisan-tulisan mereka. Mereka hanya menyebut kesatuan masyarakat dengan istilah Petulai, Sumbai, Kebuaian, atau suku, suatu kesatuan masyarakat yang dilihat dari aspek genealogis. Kesatuan masyarakat yang bersifat teritorial ini dicetuskan langsung oleh Sultan Kerajaan Palembang sebagai sebuah kebijakan pemerintah kerajaan (Muslimin, 1986: 9).

Berdasarkan artefak yang ditemukan di Lubukbesar tahun 1995 berupa stempel cap, istilah Marga dalam wilayah Musi Ulu (Muara Beliti) sudah dikenal sejak tahun 1856. Hal ini berdasarkan tulisan yang terdapat dalam stempel cap. Stempel cap tersebut adalah milik Marga Suku Tengah Kepungut daerah Moesi Oloe dengan Pesirah berkedudukan di Lubuk Besar. Marga ini masuk dalam kesatuan pemerintahan Residentie Palembang. Stempel Cap Berbentuk Bulat Lonjong dengan diameter 5,5 dan $4,5 \mathrm{~cm}$ terbuat dari bahan tembaga kuningan. Permukaan lingkaran tepi cap bertuliskan huruf Latin berbunyi "RESIDENTIE PALEMBANG MOESIE OLOE". Selanjutnya lingkaran tengah bertuliskan huruf Arab Melayu yang berbunyi "NGALAMAT PANGEYANG MARGA SUKU TENGAH KEPUNGUT TAHUN 1856". Berdasarkan keterangan pada stempel cap tersebut sampai awal abad ke-20 belum dikenal nama Musi Rawas, yang ada hanya nama Moesie Oloe Ibukota Kabupaten yang membawahi daerah Muara Lakitan,
Muara Rupit, Rawas, Sindang Kelingi, dan Sindang Beliti (Suwandi, 1995:26).

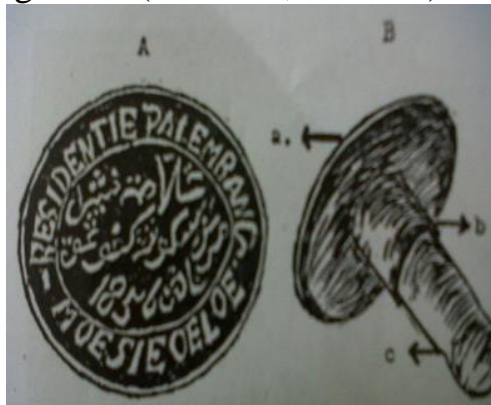

Gambar 1: Stempel Cap Marga Suku Tengah Kepungut

Sumber Foto: Suwandi, 1995: 26.

Istilah kepungutan yang terdapat dalam stempel cap menjelaskan bahwa daerah tersebut merupakan wilayah yang masuk dalam kesatuan Pemerintahan Palembang. Kepungutan berasal dari kata "pungut" yang dapat diartikan sebagai pengambilan daerah itu menjadi daerah yang dikuasai penuh oleh Pemerintahan Kesultanan. Kepungutan dibagi menurut aliran sungai dan oleh Belanda disebut sebagai Batang Hari atau Afdeeling (Muslimin, 1986:18).

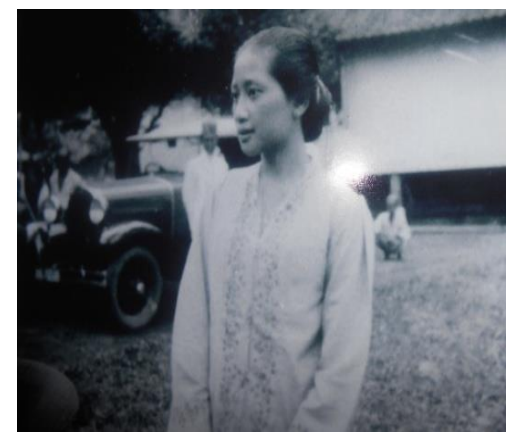

Gambar 2:Pesirah Perempuan dari Moesi Oloe, Muara Beliti.

Sumber: Kit Sumatera Selatan, Riau, Jambi No: 428/10

Sejak pemerintahan Belanda menghapuskan pemerintahan kesultanan dan melakukan pemerintahan secara langsung diadakan perjanjian dengan kesatuan masyarakat hukum yang ada, baik yang bersifat teritorial maupun genealogis, yang mengakui kedaulatan Belanda. Ketika pemerintahan Marga dilanjutkan 
oleh Pemerintahan Belanda maka dilakukan penetapan batas-batas teritorial Marga. Marga dimekarkan sebagai satu kesatuan teritorial dengan tidak menghiraukan ikatan-ikatan kekeluargaan. Hubungan kekeluargaan tidak diberlakukan lagi dan hanya menjadi ingatan pribadi. Secara politis pemerintahan dengan sistem kekeluargaan boleh dikatakan tidak berfungsi lagi (Muslimin, 1986: 26).

Tahun 1993 ditemukan Piagam Muara Kati di Desa Muara Kati Kecamatan Muara Beliti. Piagam ini sekarang menjadi koleksi museum Balaputra Dewa Palembang. Piagam ini bertuliskan huruf Latin dan huruf Melayu yang diukir dengan menggunakan tulisan indah dan menggunakan ejaan lama. Tulisan dalam piagam tersebut berbunyi: Inilah Gardoe Pangeang Moera Kati Marga Soekoe Tengah Tiang Poeng-poeng Afdeeling Moesi Oeloe, berangka tahun 1866. Dari kedua sumber dokumen Marga yang ditemukan tersebut, diperoleh keterangan bahwa pemerintahan Marga di Lubukbesar sepuluh tahun lebih tua daripada Pemerintahan Marga di Muara Kati. Keduanya dalam wilayah afdeeling Musi Ulu yang berkedudukan di Tebing Tinggi (Suwandi, 2995: 24).

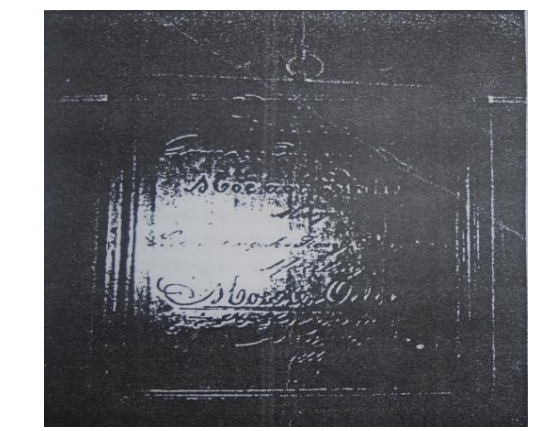

Gambar 3. Piagam Marga Suku Tengah Tiang Pung-pung tahun 1866 Sumber: Suwandi, 1995:27

Dari uraian di atas dapat dinyatakan bahwa lahirnya pemerintahan Marga mulanya berkembang dari kesatuankesatuan yang bersifat genealogis dan sudah menunjukkan ciri suatu masyarakat hukum. Dalam perkembangan selanjutnya kesatuan masyarakat yang bersifat genealogis bergeser menuju kesatuan masyarakat yang diikat oleh kesatuan teritorial. Sistem Marga juga mengikuti perkembangan ini, di mana Marga merupakan ikatan masyarakat atas dasar kesatuan teritorial dan mengesampingkan kesatuan genealogis. Sistem Marga sebagai kesatuan masyarakat hukum berdasarkan adat tersebut telah berkembang sebelum dan setelah berdirinya Pemerintahan Kesultanan Palembang. Sistem Marga ini diteruskan pada masa Pemerintah Hindia Belanda, dilanjutkan hingga kemerdekaan, dan berakhir tahun 1983 untuk selanjutnya diganti dengan sistem pemerintahan desa.

\section{Hukum dalam Pemerintahan Marga}

Marga pada dasarnya adalah daerah teritorial di bawah kekuasaan Kesultanan Palembang. Marga merupakan satuan pemerintahan yang membawahi beberapa dusun di bawah pimpinan seorang pesirah/depati. Panggilan pesirah/depati adalah pangeran. Ia bertindak sebagai kepala hukum adat yang menjalankan keputusan dan undang-undang serta ketentuan yang tercantum dalam piagam yang dikeluarkan oleh Sultan. Aturan mengenai sistem marga yang harus diikuti oleh pesirah/depati ini tercantum dalam Undang-undang Simbur Cahaya. Undangundang ini dibuat pertama kali tahun 1630 oleh Kesultanan Palembang. Undangundang ini digunakan di seluruh wilayah Kesultanan Palembang sebagai hukum adat tertulis. Kemudian ketika Belanda menguasai wilayah Kesultanan Palembang, dan melanjutkan sistem pemerintahan Marga, tahun 1854 Undang-undang Simbur Cahaya disusun kembali oleh Van Bossche. Isi dalam Undang-undang Simbur Cahaya tersebut masih mengikuti isi dari Undang-undang Simbur Cahaya yang disusun oleh Kesultanan Palembang, hanya ada penyesuaian dengan peraturan pemerintah Hindia Belanda. Seperti istilah pemerintahan diubah menjadi gouvernement. Undang-undang ini berlaku 
sebagai hukum adat tertulis di wilayah kekuasaan Keresidenan Palembang (Suwandi, 1995: 8).

Tahun 1927 dilakukan perubahan baru kitab Undang-undang Simbur Cahaya oleh Resident Van Palembang atas nama Sri Baginda Maharaja Ratu Belanda dan Gubernur Jendral Hindia Belanda. Undang-undang ini harus ditaati juga oleh masyarakat di daerah perhuluan Palembang. Undang-undang disusun dalam dua versi. Pertama, huruf Latin berbahasa Belanda dan huruf Latin berbahasa Melayu. Kedua menggunakan huruf Arab Melayu dengan bahasa Melayu (Suwandi, 1995: 9).

Undang-undang Simbur Cahaya disusun secara sistematik yang isinya mengenai Hukum Perdata, Hukum Pidana, dan Tata Pemerintahan. Menjelang abad ke-20 Pemerintah Keresidenan Palembang menerbitkan kembali Undang-undang Simbur Cahaya yang isinya mengatur tentang pemilihan, pengangkatan, dan pemberhentian kepala Marga, dusun, kampong, dan perangkat dusun. ${ }^{4}$

Aturan Marga yang tercantum dalam kitab Undang-undang Simbur Cahaya ini dipakai sejak zaman Kesultanan Palembang sampai pada zaman penjajahan Belanda, bahkan masih tetap dipakai hingga zaman kemerdekaan. Namun setelah dikeluarkannya Reglementen tanggal 20 Juni 1940, aturan Marga mengenai pengangkatan, pemilihan dan pemberhentian kepala Marga, dusun dan kampung diberlakukan menurut peraturan baru ini. Aturan ini tercantum dalam bab 2 pasal 1 s.d. 10 (Suwandi, 1995: 20).

Ketika sistem pemerintahan kesultanan dihapuskan, wilayah kesultanan menjadi wilayah yang diperintah langsung oleh pemerintah Hindia Belanda. Masyarakat hukum yang bersifat teritorial pada zaman kesultanan telah berkembang dan pemerintahan Belanda melanjutkan usaha ini dengan bekerja lebih rasional dan

\footnotetext{
${ }^{4}$ Besluit Van den Resident Van Palembang tanggal 20 Juni 1940, nomor 938.
}

sistematis. Dusun-dusun yang disebut Marga ini membentuk dua atau lebih rumpun serikat sendiri dengan anggotanya masih keturunan dari satu nenek moyang. Dasar hukum pemerintahan Marga disempurnakan dalam peraturan pokok ketatanegaraan Belanda, di mana pasalpasalnya berisi penyempurnaan mengenai batas-batas wilayah, susunan, dan kewenangan pemerintahan Marga. Penyempurnaan disesuaikan dengan kepentingan Belanda terutama dalam hal keamanan dan ketertiban. Dari dasar hukum peraturan pokok ketatanegaraan Belanda ini, pemerintah Marga dapat membuat dan melaksanakan peraturannya sendiri, meskipun tetap di bawah pengawasan pemerintah Hindia Belanda. Peraturan itu memungkinkan diadakannya penyeragaman dalam susunan dan cara pemerintahan. Belanda meletakkan dasardasar hukum mengenai kebijakan pemerintah Belanda melalui seperangkat aturan perundang-undangan.

Pada saat Belanda menguasai langsung bekas wilayah Kesultanan Palembang, kebanyakan dari ambtenaar tidak menyadari adanya susunan pemerintahan yang harus berhadapan langsung dengan masyarakat. Namun kesadaran itu berangsur-angsur muncul dengan adanya tulisan dari beberapa ambtenaar dan cendikiawan seperti $\mathrm{V}$. Vollenhoven, Logemann, Ter Haar, dan lain-lain. Timbul kesadaran tentang adanya kesatuan-kesatuan pemerintah terendah yang mandiri yang mempunyai susunan dan kewenangan yang teratur. Pada awalnya kesatuan pemerintahan itu bersifat genealogis atau berakar dari garis keturunan dan hubungan kekeluargaan. Selanjutnya berubah menuju kesatuan berdasarkan tempat tinggal dalam suatu wilayah tertentu (teritorial). Terjadi pergeseran orientasi kesatuan masyarakat yang genealogis menuju pada kesatuan masyarakat teritorial. Kesatuan-kesatuan ini mempunyai wibawa dan diliputi oleh norma-norma dan tata tertib pergaulan dan hubungan lalu lintas antarwarga yang 
teratur. Kesatuan-kesatuan ini selanjutnya dimanfaatkan oleh pemerintah Hindia Belanda untuk secara langsung memengaruhi dan mengawasi rakyat demi kepentingan Belanda. Masyarakat hukum terendah ini diberi dasar hukum dalam perundangan pokok pemerintah Hindia Belanda (Muslimin, 1986: 32-33).

Berdasarkan Staadblads Nomor 490 dan Staadblads Nomor 681 Pemerintahan Marga di wilayah Palembang dan sekitarnya merupakan kesatuan pemerintahan yang terendah berdasarkan hukum adat. Seperti dijelaskan dalam staadblads tersebut, Marga adalah masyarakat hukum adat yang berfungsi sebagai kesatuan wilayah pemerintahan terdepan dalam rangka pemerintahan Hindia Belanda dan merupakan badan hukum Indonesia. Marga berhak mengurus rumah tangganya sendiri berdasarkan hukum adat. Marga dapat mengadakan pungutan pajak dan mengadakan ketentuan-ketentuan tentang kerja badan dan cara penebusannya dengan uang (Muslimin, 1986: 54).

Susunan pemerintahan Marga, kepala Marga, dan kepala adat lainnya, bentuk dan susunan pemerintahan ditentukan menurut hukum adat berdasarkan pemilihan dan pengangkatan serta pengesahan atau pengakuan oleh instansi pemerintah (Hindia Belanda) yang ditunjuk itu. Pemerintahan Marga didampingi dewan Marga yang membuat peraturan-peraturan dalam rangka kewenangan menurut hukum adat. Peraturan-peraturan Marga harus disahkan oleh instansi atasan sebelum berlaku dan diumumkan. Pemerintahan Marga dapat menetapkan sanksi atas peraturannya, yaitu hukuman badan selama-lamanya 3 hari atau membayar 10 rupiah (Muslimin, 1986: 35).

Pada zaman Hindia Belanda, Marga merupakan kesatuan pemerintahan yang operasional berada di depan, berhadapan langsung dengan rakyat. Pemerintahan Marga dalam arti luas merupakan pembuat peraturan, pelaksana, pengawas (polisi), dan sekaligus penindakan (peradilan). Dengan demikian, pemerintah Marga dapat dikatakan melaksanakan keempat tugas itu sekaligus. Marga membuat peraturan sendiri, dan melaksanakan sendiri peraturannya, meskipun tetap harus di bawah pengawasan pemerintah Hindia Belanda.

Dari keterangan di atas dapatlah dikatakan, bahwa Marga mempunyai hak otonomi berdasarkan hukum adat, mengatur dan mengurus rumah tangganya. Marga memiliki hak legislatif, eksekutif, dan yudikatif. Dalam perkembangan selanjutnya hak peradilan tidak disebutkan lagi karena menggunakan peradilan asli (adat), dan sudah dihapuskan dengan Undang-Undang Darurat Nomor 1 tahun 1981.

Setelah undang-undang peradilan asli (adat) dihapuskan, tidak terdapat lagi peradilan, kecuali apa yang disebut sebagai Peradilan Perdamaian yaitu kewenangan kepala adat (sekarang desa) apabila diminta, menjalankan usaha-usaha mendamaikan antara warga dalam sengketa-sengketa ringan khusus bidang perdata. Badan peradilan dalam suatu Marga disebut rapat Marga, yang mengadili perkara-perkara kecil dan pelanggaran-pelanggaran adat, yang dimaklumi dalam Undang-undang Simbur Cahaya. Peradilan adat ini bukan suatu bentukan baru oleh pemerintah Hindia Belanda atau Pemerintah Kesultanan, akan tetapi berkembang secara mandiri dalam lingkungan Marga-Marga yang bersangkutan dalam memecahkan sengketa tentang perbatasan atau sanksi terhadap perbuatan yang melanggar kesusilaan atau ketertiban. Peradilan adat ini diberi dasar oleh pemerintah Hindia Belanda dalam pasal 131 ayat 5 dan peraturan pelaksanaan selanjutnya dalam ordonansi tentang peradilan asli. ${ }^{5}$

\footnotetext{
${ }^{5}$ Stadblaats No. 80 tahun 1932. Kepala Marga bertindak sebagai ketua pengadilan, sedangankan anggotanya terdiri dari proatin atau pengawa dan penghulu/ ketib.
} 
Setelah masa kemerdekaan Indonesia dan memasuki masa revolusi fisik, terjadi berbagai masalah yang bersifat negatif terutama dalam aspek hukum pemerintahan Marga. Pemerintah mengambil langkah-langkah untuk meredakan berbagai masalah hukum dalam sistem Marga ini. Provinsi Palembang mengeluarkan peratuan tentang pendemokrasian susunan dari badan-badan perwakilan Marga dengan cara pemilihan anggota pemerintah Marga mulai dari kepala Marga sampai pada pejabat-pejabat di tingkat bawah, yaitu Krio, Punggawa, Penghulu, dan Khotib. Jika pada masa pemerintahan Hindia Belanda mereka dipilih secara bertingkat, maka pada masa kemerdekaan dipilih secara langsung dan masa jabatannya tidak lagi seumur hidup namun diberikan batas waktu jabatan. Perubahan-perubahan dalam sistem pemerintahan Marga tertuang dalam peraturan-peraturan sebagai berikut.

a. Surat Keputusan Gubernur/53/51 mengenai DPRD.

b. Surat Keputusan Gubernur/54/51 mengenai pemilihan pamongpraja, penghulu, dan Khotib.

c. Surat Keputusan Gubernur 101, 111, $114 / 1951$ tentang kepala Marga dan lain-lain pamong Marga, dipilih langsung oleh rakyat.

d. Surat Keputusan Gubernur 55/1961 khusus tentang cara pemilihan Pesirah/Kepala Marga yang diangkat oleh Gubernur dari calon-calon yang diajukan oleh panitia pemilihan (Muslimin, 1986: 49-50).

Setelah dikeluarkannya beberapa surat keputusan di atas, maka selanjutnya dikeluarkan juga Surat Keputusan Gubernur Kepala Daerah Tingkat I Sumatera Selatan nomor: 142 tahun 1983 tentang penghapusan pemerintah Marga, DPR, Marga, dan perangkat Marga lainnya, pemberhentian pesirah/pejabat pesirah kepala Marga, ketua/anggota DPR. Marga dan pejabat pamong Marga lainnya serta penunjukan pejabat kepala desa dalam wilayah Provinsi Daerah Tingkat I Sumatera Selatan.

Dengan menimbang dalam rangka pelaksanaan Undang-undang nomor 5 tahun 1979 untuk pelaksanaan pemerintah desa sesuai dengan undang-undang dimaksud, dipandang perlu menghapuskan Pemerintahan Marga dalam wilayah Provinsi Daerah Tingkat I Sumatera Selatan. Dengan demikian terhitung mulai tanggal 4 April 1983, sistem pemerintahan Marga di Lubuklinggau dihapuskan dan diganti dengan sistem pemerintahan desa. Sejak itu dusun-dusun/desa-desa langsung sebagai bawahan dari pemerintahan wilayah kecamatan, artinya kepala desa/kepala dusun lurah atau gindo secara hirarkis berada di bawah camat.

\section{Pemerintahan Marga di Lubuk-linggau}

Ketika Belanda mengusai

Kesultanan Palembang, mereka berupaya menguasai daerah kesultanan sampai jauh ke daerah pedalaman melalui kegiatan ekspedisi untuk melebarkan sayap kekuasaannya dengan membuka daerahdaerah koloni baru. Pada akhirnya mereka tiba di satu daerah Kesultanan Palembang yang bernama Negeri Ulak Lebar. Daerah ini dipimpin oleh seorang pemimpin tradisional dengan gelar Depati. Letak dan kondisi Negeri Ulak Lebar tidak memungkinkan untuk perkembangan ke depan. Wilayahnya berada di kawasan dataran sempit memanjang dari barat ke timur di selatan kaki Bukit Sulap dan di sebelah utara daerah aliran sungai Kelingi ${ }^{6}$. Pusat pemerintahan masyarakat Negeri Ulak Lebar ditandai dengan benteng terbuat dari tanah yang disebut "kute". Kute merupakan tanah yang ditinggikan berbentuk pematang berfungsi sebagai pagar pembatas bagian luar dengan bagian

6 Situs Ulak Lebar terletak di Kelurahan Sidoarjo, Kec. Lubuklinggau Barat, Kab. Musi Rawas. Lokasi ini ditandai dengan Bukit Sulap, Sungai Kelingi, Sungai Kasie dan Sungai Ketue (Laporan Kegiatan Survey Investigasi Cagar Budaya dan Benda Purbakala 1995/1996). 
dalam. Tanah yang ditinggikan ini berfungsi sebagai benteng (Suwandi, 2011: $1)$.

Dusun yang berada di bawah kesatuan wilayah Negeri Ulak Lebar yaitu: Dusun Batu Kuning Lubuk Durian, Dusun Nyiur Cundung, Dusun Tanjung Genting, Dusun Tanjung Kelingi, Bukit Lenges, Bukit Tekum dan Bukit Tipis (Suwandi, 2011: 19). Sumber kehidupan pokok masyarakat Negeri Ulak Lebar pada umumnya adalah bidang pertanian dan perkebunan. $^{7} \quad$ Bidang perkebunan masyarakat menanam kapas dan karet, sedangkan untuk bidang pertanian yang utama dikerjakan oleh masyarakat adalah menanam padi. Selain bertani dan berkebun penduduk Ulak Lebar juga melakukan aktivitas merambah hutan untuk mencari biga dan damar. ${ }^{8}$

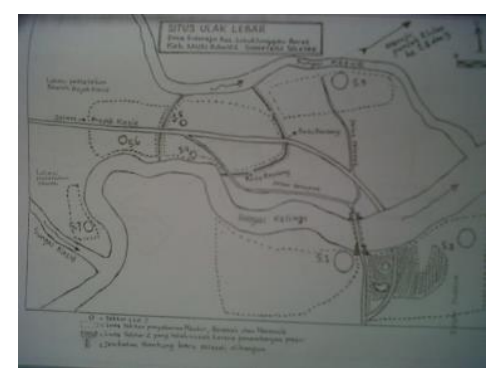

Gambar 4. Peta Lokasi Negeri Ulak Lebar Sumber: Laporan Kegiatan Surve Investigasi Cagar Budaya dan Benda Purbakala Daerah Tingkat II Musi Rawas 1996.

Berdasarkan kepentingan pengaturan dan pengawasan secara praktis oleh Pemerintah Hindia Belanda, masyarakat yang mendiami daerah tersebut (Negeri Ulak Lebara) akhirnya dipindahkan ke daerah pemukiman baru. Proses pemindahan tersebut memakan waktu yang

7 Lihat dalam: Oendang-oendang Simboer Tjahaja "oendang-oendang jang ditoeroet didalam hoeloean negeri Palembang"

8 Biga merupakan bahan campuran porselin yang sangat diminati oleh orang Cina yang diambil dari dari endapan cairan yang terdapat di dalam batang bamboo. Damar merupakan sejenis getah kayu kering yang digunakan sebagai campuran cat. cukup lama dan proses yang sangat sulit karena penduduk tidak ingin meninggalkan negeri leluhur mereka.

Hingga pada kepemimpinan Depati Japar tahun 1850, masyarakat Negeri Ulak Lebar bersedia dipindahkan oleh pemerintah Hindia Belanda untuk mendiami daerah pemukiman baru yang telah disediakan. Wilayah ini berada di daerah yang sangat strategis untuk perkembangan yang akan datang. Pesatnya pertumbuhan usaha perkebunan yang ada di daerah sekitarnya membawa pengaruh yang besar terhadap pertumbuhan daerah ini untuk masa yang akan datang. Daerah yang tadinya merupakan hutan belukar berubah menjadi pemukiman kecil tempat penduduk yang berasal dari negeri Ulak Lebar dengan sebutan Dusun Linga. Daerah pemukiman tersebut dibentuk menjelang berakhirnya masa pemerintahan Depati Japar di Negeri Ulak Lebar. Daerah pemukiman baru bagi masyarakat Negeri Ulak Lebar ini sekarang dikenal dengan nama Lubuklinggau (Suwandi, 2002: 27).

Tabel 1. Daftar nama-nama Depati Negeri Ulak Lebar

\begin{tabular}{cc}
\hline Nama & $\begin{array}{c}\text { Masa } \\
\text { Jabatan }\end{array}$ \\
\hline Depati Bodo & $1680-1720$ \\
\hline Depati Rapat & $1720-1730$ \\
\hline Depati Dukun & $1730-1745$ \\
\hline Depati Lumpuh & $1745-1780$ \\
\hline Depati Lang & $1780-1824$ \\
\hline Gandus & 1825,1830 \\
\hline Depati Abun & $1830-1835$ \\
\hline Deapti Rawas & $1835-1855$ \\
\hline Depati Japar & \\
\hline
\end{tabular}

Sumber: Suwandi, 1995:56

Pada tahun 1854, Residen Van Palembang yang bernama Van Bosche memberlakukan Kitab Undang-undang Simbur Cahaya sebagai pedoman bagi 
kepala-kepala Marga sekaligus sebagai kepala adat di daerah perhuluan seluruh Wilayah Keresidenan Palembang. Berdasarkan undang-undang tersebut, sejak tahun 1855 semua dusun yang berada di bawah kesatuan suku atau hukum adat yang belum mempunyai Marga harus segera dibentuk. Wilayah dusun atau negeri yang merupakan kesatuan suku atau hukum adat dalam wilayah pengawasan Sindang Kelingi dihimpun ke dalam Marga-Marga, yaitu: wilayah yang meliputi Dusun Kepala Curup, Padang Ulak Tanding, dan beberapa dusun lainnya sampai dengan perbatasan Lubukdurian masuk ke dalam Marga Sindang Kelingi. Kemudian untuk Dusun Lubukdurian, Dusun Kayu Ara, Dusun Lubuk Tanjung, Dusun Lubuklinggau, Dusun Kandis dan Dusun Batu Urip Tue (Tarwe) masuk dalam Dusun Marga Sindang Kelingi Ilir, dengan kepala Marganya berkedudukan di Dusun Lubuklinggau. Oleh karena itu Dusun Lubuklinggau berstatus sebagai Dusun Marga tempat kedudukan kepala Marga Sindang Kelingi Ilir yang membawahi beberapa dusun. Saat itu Lubuklinggau berada dalam teritorial kekuasaan Kesultanan Palembang yang telah diatur oleh Belanda (Suwandi, 2001: 27-28). Tahun 1907 Dusun Marga Sindang Kelingi Ilir berada dalam wilayah kekuasaan onderafdeeling Musi Ulu yang beribu kota di Muara Beliti.

Sejak diberlakukannya sistem Marga, masyarakat Marga Sindang Kelingi Ilir, baik yang berdiam di Dusun Lubuklinggau maupun yang berdiam di dusun penyangganya, mulai mengikuti ketentuan yang berlaku menurut Undang-undang Simbur Cahaya. Akan tetapi hukum adat yang telah ada sebelumnya tetap dijalankan. Meskipun Dusun Lubuklinggau sudah berstatus Dusun Marga Sindang Kelingi Ilir yang artinya kesatuan masyarakat hukum adat tidak lagi berdiri sendiri, karena ada beberapa kesatuan masyarakat hukum adat lainnya yang berada di bawahnya yang terdiri dari masyarakat dusun-dusun penyangga, namun kepala Marganya tetap memakai gelar depati. Hal ini berlangsung hingga tahun 1936 ketika gelar Depati Marga Sindang Kelingi Ilir dihapuskan dan berganti dengan gelar pesirah (Suwandi, 2002:31).

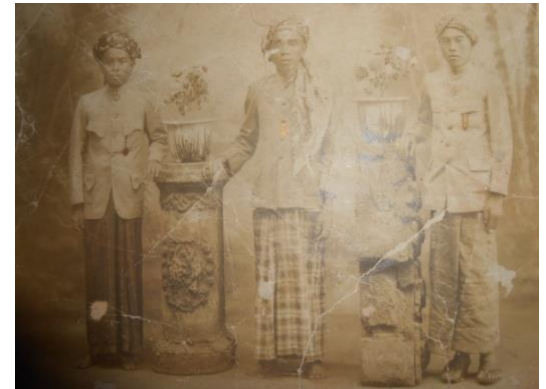

Gambar 5. Pesirah Marga Sindang Kelingi Ilir tahun 1936

Sumber: Musium Subkoss Garuda Sriwijaya Lubuklinggau

Tahun 1855 Depati Japar mengundurkan diri. Untuk mencari penggantinya dilakukan pemilihan kepala Marga. Sistem pencalonan dan pemilihan kepala Marga sudah diatur dalam Undangundang Simbur Cahaya. ${ }^{9}$ Dalam aturan tersebut dinyatakan bahwa pesirah atau kepala Marga dipilih oleh orang banyak. Selanjutnya raja mengangkat serta memberi gelar kepada calon yang terpilih. Berdasarkan Reglementen Residen van Palembang tanggal 20 Juni 1940 nomor 939. Syarat-syarat menjadi calon pesirah/depati adalah sebagai berikut:

1. telah beristri;

2. sudah dewasa dan berpikiran sempurna;

3. berjenis kelamin laki-laki yang merupakan penduduk asli Marga setempat dan belum pernah memutuskan hubungan dengan Marga tersebut;

4. cukup paham dalam hal membaca dan menulis huruf Latin (Belanda);

5. belum pernah dijatuhi hukuman penjara karena kejahatan lebih dari satu tahun, kecuali residen memutuskan lain.

\footnotetext{
${ }^{9}$ Diatur dalam Bab 2 Pasal 1.
} 
Kepala Marga yang terpilih untuk memimpin Marga Sindang Kelingi Ilir yaitu Nasir yang masih bergelar depati. Masa pemerintahan Depati Nasir cukup lama dari tahun 1855-1874 namun dalam masa pemerintahannya tidak terdapat hal yang signifikan dalam perkembangan Dusun Marga Sindang Kelingi Ilir. Sejak diberlakukannya sistem Marga, masyarakat Marga Sindang Kelingi Ilir, baik yang tinggal di Dusun Lubuklinggau maupun yang tinggal di dusun sekitarnya-Lubuk Durian, Kayu Ara, Lubuk Tanjung, Kandis, dan Batu Urip - mulai mengikuti ketentuan yang berlaku menurut Undangundang Simbur Cahaya. Sementara itu hukum adat yang telah dijalankan selama ini masih tetap berlaku dan tidak ditinggalkan (Suwandi, 2002: 28).

Tahun 1874 terjadi lagi pergantian depati dalam Marga Sindang Kelingi Ilir. Dalam pemilihan depati tersebut yang terpilih sebagai pengganti depati Nasir adalah Pengacing yang kemudian diberi gelar depati. Depati Pengacing memerintah dusun Marga Sidang Kelingi Ilir selama enam tahun sejak tahun 1874-1879. Setelah itu Marga Sindang Kelingi Ilir dipimpin oleh seorang depati bernama Depati Said, dengan masa pemerintahan selama enam tahun dari tahun 1879-1884. Depati selanjutnya bernama Depati Kademen (1884-1895), setelah masa jabatan Depati Kademen berakhir, selanjutnya digantikan oleh Depati Kodir. Masa pimpinan Depati Kodir (1895-1916), setelah itu digantikan oleh Depati Ramitan (1916-1936). Setelah masa kepemimpinan depati Ramitan berakhir, untuk periode selajutnya Kepala Marga Sindang Kelingi Ilir tidak lagi bergelar depati namun bergelar pesirah. Penggati dari Depati Ramitan adalah Pesirah Naning terpilih sebagai pesirah sejak tahun 1936-1942 (Suwandi, 1995: 56).

Sebelum pemerintahan Belanda melakukan pemerintahan secara langsung tahun 1851, pemerintah kesultanan telah memanfaatkan lembaga pemerintahan asli dari rakyat ini yang berkembang dengan budaya dari rakyat sendiri. Pemerintah Belanda kemudian melanjutkan sistem pemerintahan ini dengan mengadakan tindakan menyeragamkan (legalisasi) beberapa macam tugas kekuasaan dan bentuk kesatuan yang dimaksud dalam sistem pemerintahan.

Kewibawaan Belanda dalam menjalankan pemerintahan dan pelayanan terhadap rakyat justru tumbuh dengan mempergunakan kesatuan-kesatuan pemerintah asli dengan biaya dan usaha yang relatif ringan. Pemanfaatan kesatuan lembaga pemerintahan asli dari rakyat ini diteruskan oleh Pemerintahan Militer Jepang. Pada masa Pemerintahan Militer Jepang Marga Sindang Kelingi Ilir dipimpin oleh pesirah Sa'ari. Meskipun dalam statusnya pemerintahan Marga telah dibekukan oleh Pemerintah Militer Jepang, namun sebagai pemimpin tradisional masih dimanfaatkan oleh Pemerintah Jepang. Hal ini tidak lain untuk kepentingan Perang Asia Timur Raya. Pemerintah Militer Jepang memanfaatkan para pemimpin elit tradisional ini dalam pengumpulan tenaga kerja (romusha) dan pengumpulan bahan pangan (padi, sayur, jagung, dan umbiumbian).

Memasuki kemerdekaan 1945 pemerintahan Marga Sindang Kelingi Ilir di Lubuklinggau dipimpin oleh Pesirah Naning. Pesirah Naning menjabat untuk kedua kalinya dalam Pemerintahan Marga Sindang Kelingi Ilir, yaitu pada masa awal kemerdekaan dan masa gejolak perang gerilya melawan tentara Belanda dalam agresi militer Belanda pertama dan agresi militer Belanda kedua sampai pada pelaksanaan pemilihan umum yang pertama tahun 1955 .

Semasa perjuangan rakyat menentang usaha Belanda dalam tindakan agresinya untuk menduduki kembali Indonesia, pemerintahan Marga di Lubuklinggau berperan penting dalam mendukung perjuangan revolusi. Sampai saat penyerahan kedaulatan tahun 1949, kesatuan pemerintahan Marga memberikan bantuan pada Tentara Republik dan banyak 
berjasa dalam mengobarkan semangat perjuangan rakyat menentang pendudukan Belanda. Namun di lain pihak terjadi hal lain yang tidak dapat dilupakan pada masa revolusi fisik, yaitu banyaknya kepala Marga yang diculik dan dibunuh. Hal ini terjadi karena para kepala Marga lamban menyesuaikan diri dengan zaman revolusi. Kasus ini dilatarbelakangi oleh perasaan balas dendam dari golongan rakyat tertentu kepada para kepala Marga. Ketika masa pendudukan Jepang melakukan pemaksaan dalam pengumpulan bahan makanan dari rakyat, para kepala Marga dijadikan kaki tangan Jepang dalam pengumpulan bahan makanan. Akibatnya, masyarakat menaruh dendam kepada para kepala Marga.

Untuk menenangkan kondisi kacau yang demikian, pemerintah mengeluarkan peraturan baru bagi pemerintahan Marga. Aturan-aturan itu ditujukan untuk menciptakan kehidupan rukun dan damai dalam wilayah pemerintahan Marga. Kondisi ini terus berjalan hingga sistem pemerintahan Marga dihapuskan. Sebelum sistem pemerintahan Marga dihapuskan, setelah masa revolusi fisik, pemerintahan Marga Sindang Kelingi llir dipegang oleh Pesirah Kohar yang merupakan anak dari Depati Remitan. Pesirah Kohar menjabat selama periode 1956-1967. Setelah masa jabatannya berakhir, Pesirah Kohar digantikan oleh Burhan Aliakin dengan masa jabatan selama 1965-1972. Selama masa kepemimpinan Pesirah Burhan Aliakin, pemerintahan Marga Sindang Kelingi Ilir membawahi tiga belas dusun. Hal itu didasarkan pada Peraturan Daerah Nomor: $\quad$ 2/DPR.GR.SS/1969 yang dikeluarkan oleh Pemerintah Daerah Tingkat I Sumatera Selatan. Marga Sindang Kelingi Ilir di bawah pemerintahan Kecamatan Kota Lubuklinggau dan untuk Kecamatan Kota Lubuklinggau sendiri merupakan bagian wilayah administratif Kabupaten Daerah Tingkat II Musi Rawas.

Selanjutnya pesirah terakhir yang mejabat dalam pemerintahan Marga Sindang Kelingi Ilir sebelum pemerintahan yang bersifat tradisional ini dihapuskan adalah Pesirah Riduan Naning. Ia menjabat sebagai pesirah selama 19721983. Setelah itu berdasarkan Keputusan Gubernur Kepala Daerah Tingkat I Sumatera Selatan nomor: 142 tahun 1983, sistem pemerintahan Marga dihapuskan. Meskipun demikian, status Marga-Marga tetap diakui sebagai kesatuan masyarakat hukum adat dengan sebutan Lembaga Adat sepanjang menunjang kelangsungan pembangunan dan Ketahanan Nasional.

Tabel 2. Daftar Nama-nama Depati/ Pesirah Marga Sindang Kelingi Ilir tahun 1855-1983

\begin{tabular}{ll}
\hline \multicolumn{1}{c}{ Nama } & \multicolumn{1}{c}{$\begin{array}{c}\text { Masa } \\
\text { Jabtan }\end{array}$} \\
\hline \multicolumn{2}{c}{ Periode Hindia Belanda } \\
\hline Depati Japar & 1855 \\
\hline Depati Nasir & $1855-1874$ \\
\hline Depati Pengacing & $1874-1879$ \\
\hline Depati Said & $1879-1884$ \\
\hline Depati Kademen & $1884-1895$ \\
\hline Depati Kodir & $1895-1916$ \\
\hline Depati Ramitan & $1916-1936$ \\
\hline Pesirah Naning & $1936-1942$ \\
\hline \multicolumn{2}{c}{ Periode Pendudukan Militer } \\
\multicolumn{2}{c}{ Jepang } \\
\hline Pesirah Saari & $1942-1945$ \\
\hline \multicolumn{2}{c}{ Periode Kemerdekaan } \\
\hline Pesirah Naning & $1945-1956$ \\
\hline Pesirah Kohar & $1956-1965$ \\
\hline Pesirah Burhan A & $1965-1972$ \\
\hline Pesirah Riduan N & $1972-1983$ \\
\hline Sumber: Suwandi, 1995: 56
\end{tabular}

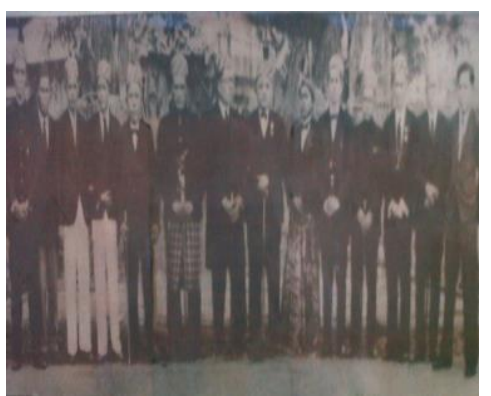

Gambar 6. Mantan Pangeran/ exs Kepala Marga dalam Daerah Tingkat II Kabupaten Musi Rawas tahun 1982.

Sumber: Koleksi Musium Subkoss Garuda Sriwijaya Kota Lubuklinggau 


\section{PENUTUP}

Sistem pemerintahan Marga berlangsung sudah sejak lama di wilayah Provinsi Sumatera Selatan, namun asal usul Marga ini tidak diketahui secara pasti. Berdasarkan catatan dari Van Royen, kata Marga berkembang dalam beberapa tahapan-tahapan yang kemudian istilah Marga lahir sebagai suatu kesatuan dalam masyarakat. Perkembangan selanjutnya mengenai Marga yaitu berdasarkan karangan-karangan ambtenaar Belanda dan beberapa temuan piagam serta stempel cap yang menjelaskan tentang pemerintahan Marga. Dari karangankarangan ambtenaar Belanda dapat dipetik bagian-bagian yang merupakan bahanbahan yang memberikan gambaran tentang sejarah perkembangan pemerintahan Marga serta dapat dibuat suatu proyeksi tentang sejarah perkembangan dan asal usul kesatuan pemerintahan yang disebut Marga.

Pemerintahan Marga merupakan pemerintahan yang bersifat tradisional, dengan hukum yang timbul dan berkembang dari budaya asli dan sifatnya kekeluargaan. Sistem pemerintahan Marga diatur dalam Undang-undang Simbur Cahaya. Undang-undang Simbur Cahaya merupakan peraturan hukum adat yang berlaku dan wajib dipatuhi oleh setiap pemerintahan Marga. Diberlakukannya Undang-undang Simbur Cahaya tersebut sebagai suatu pedoman untuk hukum adat yang akan diterapkan.

Pemerintahan kesultanan telah memanfaatkan lembaga pemerintahan ini dengan modifikasi-modifikasi dalam sistem pemerintahannya. Setelah Belanda menguasai wilayah kesultanan maka pemerintahan ini dilanjutkan dengan mempergunakan kesatuan pemerintahan asli serta menyeragamkan beberapa macam tugas kekuasaan dan bentuk kesatuan yang dimaksud. Pemerintah Belanda kemudian membuat hukum yang lebih luas lagi dan lebih jelas.

Setelah pemerintah Hindia Belanda membuat hukum yang jelas, dengan membuat dan memberlakukan undangundang tentang pembentukan Marga, maka Lubuklinggau pada tahun 1855 dijadikan sebagai Pemerintahan Marga yang membawahi beberapa dusun dan kemudian pada masa kemerdekaan tahun 1983 sistem pemerintahan Marga yang telah berlangsung cukup lama dalam wilayah Lubuklinggau dihapuskan. Hal ini berdasarkan Surat Keputusan Gubernur Kepala Daerah Tingkat I Sumatera Selatan Nomor 142 tahun 1983.

\section{UCAPAN TERIMA KASIH}

Penghargaan dan Terima kasih yang tak terhingga penulis alamatkan kepada Bapak Reiza D. Dienaputra dan Bapak Mumuh Muhsin Zakaria yang telah memberikan bimbingan dan arahan berkenaan dengan penelitian dan penulisan artikel ini. Ucapan terima kasih juga saya sampaikan kepada bapak Suwandi Syam selaku sejarawan Kota Lubuklinggau, dan merupakan kepala pimpinan Musium Subkoss Garuda Sriwijaya Lubuklinggau serta sebagai Dosen Sejarah di STKIP PGRI Kota Lubuklinggau yang telah banyak membantu penulis dalam melakukan penelitian dengan memberikan informasi dan sumber-sumber yang penulis butuhkan untuk menulis artikel ini.

\section{DAFTAR SUMBER}

\section{Arsip}

Besluit van den resident van Palembang. dd. 20 Juni 1940. No 938. Jakarta :ANRI.

Stadblaad. 1932.

Tetang Peradilan. No 80. Jakarta: ANRI.

Lembaran Negara. 1983.

Surat Keputusan Gubernur Kepala Daerah Tingkat I Sumatera Selatan. No 142. Jakarta: ANRI.

\section{Buku}

Anonim. 2001.

Kompilasi Adat Istiadat Kabupaten Musi Rawas. Palembang: Meru. 
Gottschalk, Louis. 1985.

Mengerti Sejarah. Terj. Nugroho

Notosusanto. Jakarta: UI Press.

Herlina, Nina. 2011.

Metode Sejarah. Bandung: Satya Historika.

Muslimin, Amran.1986.

$$
\begin{aligned}
& \text { Sejarah Ringkas Perkembangan } \\
& \text { Pemerintahan Marga/Kampung } \\
& \text { Menjadi Pemernitah Desa/Kelurahan } \\
& \text { dalam Propinsi Sumatra Selatan. } \\
& \text { Palembang: Pemerintahan Provinsi } \\
& \text { Sumatra Selatan. }
\end{aligned}
$$

Kartodirdjo, Sartono 1992.

Pendekatan Ilmu Sosial dalam

Metodologi Sejarah. Jakarta :

Gramedia.

Suwandi. 1995.

Pemerintahan Marga ;Tinjauan pada Masa Kesultanan Palembang dan Masa Pemerintahan Hindia Belanda. Lubuklinggau: STKIP PGRI.

--------. 2002.

Sejarah Museum SUBKOSS Garuda Sriwijaya di Lubuklingau.

Lubuklinggau: Yayasan SUBKOSS.

2011.

Historiografi Lubuklinggau. Lubuklinggau: STKIP PGRI.

\section{Laporan Penelitian}

Suwandi. 1996.

Laporan Kegiatan Survey Investigasi Cagar Budaya dan Benda Purbakala Daerah Tingkat II Musi Rawas Tahun Anggaran 1995-1996. Laporan Penelitian. Lubuklinggau: Pemerintah Kabupaten Musi Rawas. 